Article

\title{
A Concept Tree of Accounting Theory: (Re)Design for the Curriculum Development
}

\author{
Yining Zhou \\ Sydney City School of Business, Top Education Institute, Eveleigh, NSW 2015, Australia; \\ yining.zhou@top.edu.au
}

Received: 10 March 2019; Accepted: 16 May 2019; Published: 21 May 2019

check for updates

\begin{abstract}
This study contributes to both accounting and concept mapping literature through the depiction of a concept tree based on the Accounting Theory curriculum, which has undergone recent and rapid expansion of its knowledge and has hence outgrown the previous limited mapping work. This tree-shaped concept map not only accounts for a particular mapping approach little studied and scarcely exemplified in literature, but also signifies a creative model that graphically interprets the sophisticated system of accounting theories and concepts as well as their complex interrelationships. In teaching practices, this concept tree has attested a potential to promote curriculum development, as evidenced in sequence and cohesion of topics and by being linked meaningfully to exam design.
\end{abstract}

Keywords: concept map; concept tree; accounting theory; accounting education; curriculum development

\section{Introduction}

Concept maps have been proven to be a useful educational technique, integrating semantic relationships between concepts into node-link diagrams [1,2]. A traditional or Novakian concept map is made up of nodes of concepts, links, and linking phrases that articulate how these concept nodes relate to each other [3]. Through the provision of visual and abstract evident graphic depictions, concept maps can be used to aid organization, preparation, and presentation of information concerning a topic, a lecture, a course, or even a discipline of knowledge [2]. In higher education, concept mapping has been well regarded as a powerful and versatile tool to facilitate learning (particularly beneficial for lower performance students) [4,5], to enhance learners' problem-solving abilities [6,7], to foster knowledge sharing and social artefacts between students [7], to further teacher-learner dialogue [8], and to renew assessment modes from rote recall of isolated knowledge pieces towards connections between ideas [9].

Given its extensive use in a variety of (particularly science-based) disciplines, concept mapping has not received much attention in accounting education $[10,11]$. Of particular concern is its limited application in the Accounting Theory (and Application) course, where only one curriculum concept map (Simon 2007) has been found from literature thus far [4]. The essential problem is a map-knowledge mismatch. Proposed more than one decade ago and laid on a traditional financial position, Simon's map is unable to sufficiently and appropriately account for the current state of curriculum knowledge, as the system has been profoundly reshaped by theorizing accountability that triggers emergence and development of non-financial accountings [12-15]. Another inadequacy of this map is that it portrays only simple hierarchical relationships used to distinguish between "more general" and "more specific" concepts and is thus unable to make references to curriculum themes such as accounting evolution and sector-specificity, which are required to address the connections and the interconnections among accounting theories and models across different categories. It has been highlighted that concept maps can serve as powerful tools for educators and students to tackle the challenge emerging from the increasing amount and complexity of knowledge, where more sophisticated and alternative thoughts 
to the existing understanding are continuously generated [5,9]. In this regard, concept maps enable a "knowledge integration" process towards a higher level of knowledge, through which the connections between the old and the new ideas are rigorously explored, and the repertoire of all these inconsistent ideas is systematically rearranged [9]. From this perspective, it is necessary to update the curriculum concept map specified on both the extended, nonfinancial knowledge domain of accounting alternatives to traditional financial accounting [1,16], and the intricate (inter)relationships within.

On the other hand, a particular form of concept maps is to symbolize the system of knowledge or information in a tree structure $[17,18]$. The presentational effectiveness of tree models is highly praised in such a knowledge system where an evolutionary strain is implicated among concepts, or they are distinctively diversified in contexts of meanings or fields of applications $[19,20]$. This characteristic inherent to the tree model provides the opportunity to redesign the concept map for the Accounting Theory curriculum, where the financial and the non-financial accounting contexts have been distinctly differentiated but still share the same root of accountability.

The purpose of this paper is to contribute an instructor-prepared tree-like concept map stipulated on the Accounting Theory curriculum. Two insights are concluded from this study. First, the concept tree stands for a creative model that visualizes the sophisticated system of accounting theories and concepts, as well as their complex interrelationships. Second, this tree has proven its potential to promote curriculum development, as evidenced by the sequence and cohesion of topics and a meaningful linkage to exam design. An additional contribution made by this paper is the enrichment of the concept mapping methodology. In doing so, this paper constructs a concrete account to explore the tree-shape as a particular mapping technique that has been rarely studied and inadequately exemplified in literature.

\section{Concept Map in Accounting Education and a Critique of the Old Curriculum Map}

The theoretical ground of concept mapping is traced back to Ausubel's meaningful learning theory [21,22], which is based on the idea that memory-testing or rote learning cannot achieve an efficient learning process. In Ausubel's view, a successful learning process requires a platform or scaffolding through which new knowledge can be absorbed and integrated to the previously-attained knowledge. This platform or scaffolding comes from the notion of "advance organizers", which refers to a knowledge construction method where general or abstract ideas work to depict an overview to assimilate new knowledge, and fragments of texts are reasonably linked [23,24].

Ausulbel's meaningful learning theory [21-23] provides critical insights for Novak's groundwork for the development of concept mapping [1,24], which has been versatile and flexible in its application for a variety of educational purposes. The underpinning idea of concept mapping is that meaningful learning can be realized by means of graphic representation, where the already-acquired knowledge pieces are organized into an integrated system, and this system opens to new knowledge as its future components $[1,10,25,26]$. Novak and Gowin [1] refine three fundamentals of Ausubel's learning theory as the base of concept mapping:

- Hierarchical structure refers to knowledge as part of an inclusive and systematic framework.

- Progressive differentiation is defined as engendering new concepts and ideas as knowledge deepens.

- Integrative reconciliation elucidates interrelationships between concepts.

Concept mapping has been regarded as an effective teaching and learning tool in accounting education. Relevant studies fall into to three schemes: making instructor-prepared accounting concept maps, teaching accounting students how to make concept maps, and assessing effectiveness of concept maps. These research themes are shown in the Table 1.

In the first scheme, the researchers themselves act as the creators of concept maps and use these maps as educational tools for the purpose of enhancing students' understandings of academic content. In the second scheme, the researchers, as concept map educators, equip students with the knowledge of how to design concept maps. Consequently, students create their own concept maps from a particular 
topic of accounting, and they are expected to be able to use this useful tool in other fields of accounting and non-accounting disciplines. The third scheme targets assessing the effectiveness of concept maps in contributing to the improvement of education quality; this is normally done by comparing students with experience using concept maps in the curriculum with those who have no such experience.

Table 1. Research schemes of concept mapping in accounting education.

\begin{tabular}{cl}
\hline Research Schemes & \multicolumn{1}{c}{ Articles } \\
\hline $\begin{array}{c}\text { Making } \\
\text { instructor-prepared } \\
\text { concept maps to } \\
\text { enhance learning }\end{array}$ & $\begin{array}{l}\text { Simon (2007) designs a curriculum concept map for Accounting Theory [10]; } \\
\text { Handy and Polimeni (2017) propose six concept maps that correspond to six topics } \\
\text { of the Introductory Managerial Accounting curriculum [27]; } \\
\text { Mass and Leauby (2014) introduce a concept map for the topic of financial reporting } \\
\text { standards in the financial accounting curriculum [28]. }\end{array}$ \\
\hline \multirow{2}{*}{$\begin{array}{c}\text { Teaching accounting } \\
\text { students to produce } \\
\text { concept maps }\end{array}$} & $\begin{array}{l}\text { After informing students about the steps of concept mapping, Shimerda (2007) } \\
\text { presents student-prepared concept maps for the accounting equation topic, then } \\
\text { indicates usefulness of concept mapping in accounting education [29]. } \\
\text { Simon (2007) shows some instructor-prepared maps as the guidance for accounting } \\
\text { students to create their own concept maps [25]. }\end{array}$ \\
\hline $\begin{array}{c}\text { Assessing effectiveness } \\
\text { of concept maps in } \\
\text { accounting }\end{array}$ & $\begin{array}{l}\text { Mass and Leauby (2005) compare two groups of students undertaking two } \\
\text { accounting topics of income statement and cash flow statement. Its finding claims } \\
\text { that the group using concept maps had a better understating of the two topics than } \\
\text { the other group taught under the traditional instruction method [30]. } \\
\text { Leauby et al. (2010) appraise concept maps as a valuable learning tool as a result } \\
\text { from the survey response from students who used the concept map method in the } \\
\text { introductory accounting courses [11]. }\end{array}$ \\
\hline
\end{tabular}

This paper appertains to the first research scheme in an attempt to redesign a concept map to improve the Accounting Theory curricula. Given that current literature has highly appraised the student-generated concept mapping activities and teacher-student interactive mapping process for their contributions to an active learning environment, teacher-prepared or expert-made concept maps maintain an essential role in teaching practices $[5,9,31]$. Schewendimann emphasizes that teacher-made concepts "could support integrative understanding" and that, compared to student-generated maps, teacher-made maps seemingly "have an equally positive effect on improving students' achievement" [5] (p. 82). In particular, students suffering weak verbal ability or insufficient prior knowledge benefit greatly from expert-made or instructor-prepared concept maps by recalling more central ideas from these maps than from texts [5].

The new curriculum concept map developed in this paper provides an alternative to the old version of mapping (Simon 2007), which draws on a narrow financial accounting perspective and makes weak presentations of the connections between concepts [10]. Simon's map is shown in Figure 1.

Simon's work stands as the singular concept mapping attempt for the Accounting Theory curriculum in previous literature, but it suffers from some serious limitations [10]. First, drawing on a financial orientation, this map has lost its comprehensiveness in depicting up-to-date curriculum knowledge system, where the accounting academy has highlighted non-financial development and theorized accountability as the accounting base [12-15].

Second, Simon's map fails to capture the intricate interconnections among accounting theories, concepts, and models. This problem places this map at a disadvantage in teaching some curriculum themes that draw on these interrelationships, such as accounting evolution and sector-specificity of accounting practices (that is, practices of the same accounting principles vary significantly across different accounting sectors).

Third, the linking phrases such as "can be" and "e.g." substantively used in this map are too simple, superficial, and unprofessional to effectively characterize the relationships between concepts. Canas, Novak, and Reiska comment that "excellent maps are explanatory, not descriptive" - that is, the quality of maps depends on their "depth of explanation" (p. 15) [8]. Therefore, the real problem 
for concept mappers is not an ability to identify concepts to be linked, but the ability to determine propositions to provide a clear explanation, including the professional narratives labeled on these links [8]. Kinchin highlights that concept mapping expertise is evidenced in "technical terms to apply in linking phrases to increase the explanatory power of the map" (p. 291) [32]. Simon's map tends to be of underdeveloped maps, which, as Kinchin critiques, "have used simple linking phrases to join the concepts together" (p. 298) [32].

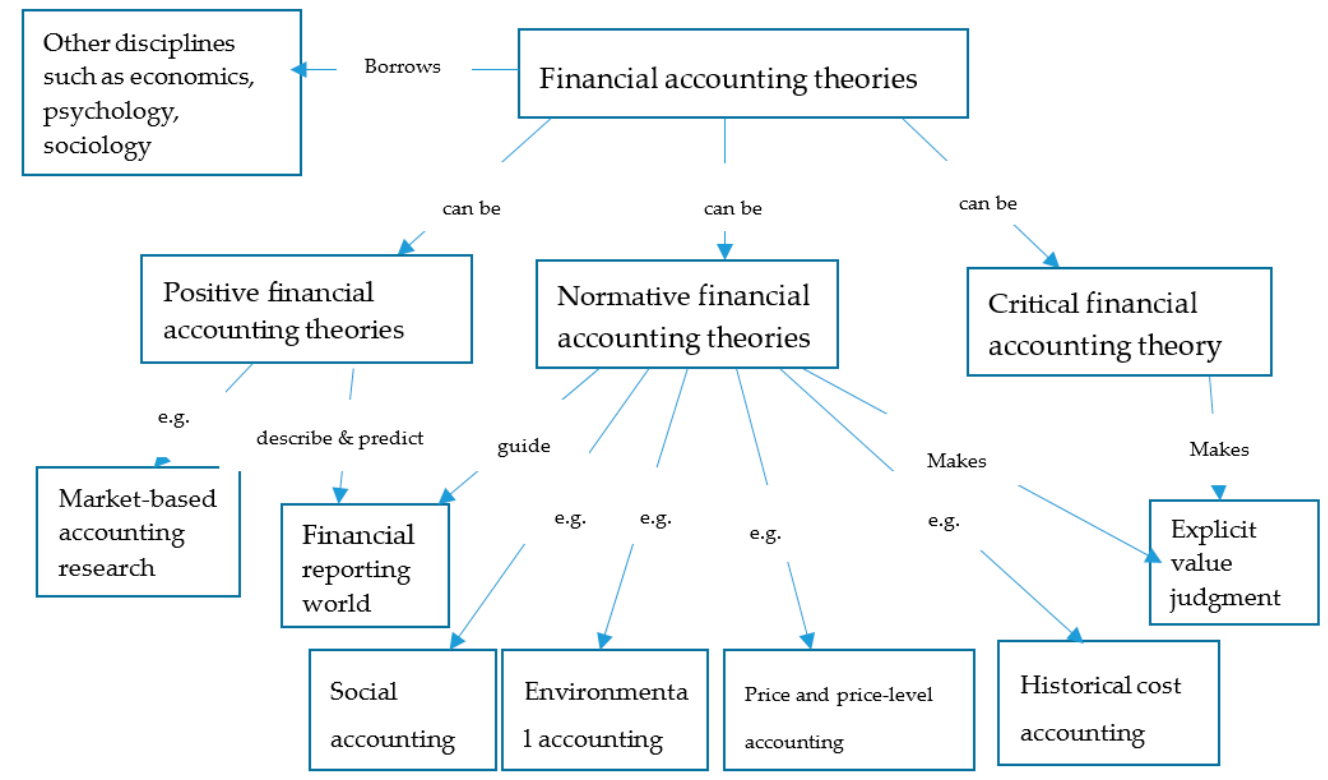

Figure 1. The old version of the curriculum concept map for (financial) Accounting Theory, sourced from Simon (2007) [10] with trivial modifications.

All the aforementioned problems are tackled in this paper by means of a new curriculum concept map using a tree model. How this concept tree is designed and how it differs from the previous mapping work are subjects further discussed in the following sections.

\section{Design of the Concept Tree for the Curriculum of Accounting Theory}

\subsection{The Tree Concept Map and Accounting Theory Knowledge}

The tree form of concept maps, or the concept tree model, has been recognized in literature as one of the basic structures of concept maps $[17,18]$. Normally, concept trees are suitable for a knowledge system where concepts can be sorted into distinctly comparative classes and sub-classes. Recent development of the accountability perspective provides the opportunity to use a concept tree to (re)model the knowledge system of accounting theories. First, theorizing accountability as the base of accountings has become a generally accepted perspective and a robust thread throughout various accounting practices $[13,15,33]$. An accountability structure involves two interrelated social actors, called "accountor" and "accountee", where the accountor has an obligation to give an account that justifies her/his performance to the accountee [34-37]. As Shearer notes, "accounting practices enact accountability" (p. 569) [15], and accountability pervades the entire accounting phenomenon. To illustrate this, the ultimate purpose of traditional financial accounting is to enable a governing body of the reporting entity to discharge accountability to shareholders [37]. Comparatively, the objective of sustainability accounting is for the entity to discharge accountability to stakeholders [33,38-41].

Second, the diversification of accounting contexts/sectors is justified from an analytic perspective of accountability. Table 2 presents the accountability relationships that regulate practices in the three main accounting contexts/sectors, including corporate financial accounting, public-sector accounting, and sustainability accounting. 
Table 2. Accountability and accounting contexts/sectors.

\begin{tabular}{cccc}
\hline $\begin{array}{c}\text { Accounting } \\
\text { Contexts/Sectors }\end{array}$ & Accountor & Accountee & Account \\
\hline $\begin{array}{c}\text { Corporate financial } \\
\text { accounting }\end{array}$ & $\begin{array}{c}\text { Corporation } \\
\text { /business entity }\end{array}$ & Shareholders & General-purpose financial reports \\
\hline Sustainability accounting & $\begin{array}{c}\text { Corporation } \\
\text { /business entity }\end{array}$ & Stakeholders & Formal and informal environmental and \\
social reports
\end{tabular}

\subsection{The Sketch of the Concept Tree}

In this redesign, the concept tree comprises the root, the trunk, the branches, the twigs, and the sub-twigs, all of which correspond to different concepts in different levels of the curriculum knowledge system.

Root: accountability denotes the root of the knowledge system, for it is the base of all accounting practices.

Trunk: the trunk is symbolized by the traditional (corporate) financial accounting as the mainstream accounting knowledge sphere. Financial accounting acts as the prototype for other accounting systems, including public-sector accounting and sustainability accounting. Both non-financial accounting systems entail a stage of simulating the traditional financial accountancy. It has been a zealous belief that public sector accounting originates from, mirrors, and keeps in line with corporate financial accounting [43-45]. Likewise, sustainability accounting is developed from the track of the financial accounting system $[12,46]$.

Branches: sustainability accounting and public-sector accounting are denoted as two branches diversified from the trunk, which stands for the mainstream (corporate financial) accounting. Their emergence and development are attributed to critical stances against the conventional accountancy, and standards and practical models associated with the two accounting systems are comparable to but significantly different from the financial accounting venue $[12,44]$. For example, sustainability accounting standards are inhered with non-financial and not-for-profit elements in establishing the accounting scopes, principles, and procedures $[39,40]$. Barton compares public-sector accounting and corporate financial accounting, attributing the considerable variances between the two systems to "differences in the roles and operating environment of governments and business" [44].

Twigs and sub-twigs: twigs signify academic schools and streams within an accounting context/sector (branch). Associated with the schools or streams are sector-specific standards, principles, and theories, which are denoted as sub-twigs. For example, the stream of capital market research is a twig of the financial accounting branch, including sub-twigs such as the efficient market hypothesis. There are lower levels of sub-twigs, such as the practical models to operationalize the standards and the principles. For example, the historical cost alternative (sub-twig) is operationalized into lower-level sub-twig models of economic value, net realized value, replacement cost, and deprival value.

\subsection{Bifurcations}

Bifurcations address the idea of "threshold concept", which refers to "a transformed way of understanding, or interpreting, or viewing something" (p. 1) [45]. A bifurcation symbolizes a threshold from which a new accounting branch/twig emerges from the conventional accounting venue. It marks the conflicting assumptions between two accounting branches or twigs that can be alternative to each other. The signposts labeled in bifurcations are used to express the rationales that underpin such inconsistencies and conflicts between concepts or theories. For example, the bifurcation between the financial accounting trunk and the sustainability accounting branch is labeled with the signpost, "financial versus non-financial", denoting the non-financial element that distinguishes sustainability 
accounting from its traditional counterpart. Another example is the twig-to-twig bifurcation with a sign of "historical cost versus anti-historical cost" to distinguish between financial reporting and the alternative measurement method. It suggests financial reporting is underpinned by the historical cost assumption, whilst the alternative measurement methodologists adopt an opposing stance to this assumption.

\subsection{Linking Phrases}

Twig notes are used as linking phrases to explain relationships between a higher level concept and a lower level concept, e.g., between a branch and a twig, or between a twig and its sub-twig. These twig notes (linking phrases) are shown in the Table 3.

Table 3. Twig notes as linking phrases.

\begin{tabular}{ccl}
\hline Twig notes & Abbreviation & \multicolumn{1}{c}{ Examples } \\
\hline Consist(s) of & C & Accounting principles consist of materiality. \\
\hline Be derived from & D & Capital market research is derived from market efficiency hypothesis. \\
\hline Be in the form of & F & Creative accounting can be in the form of "window dressing". \\
\hline Be to guide & G & Financial reporting standards are to guide "recognition" of financial items. \\
\hline Be operationalized as & O & Alternative costs can be operationalized as deprival value. \\
\hline Regulates & R & $\begin{array}{l}\text { Accountabiltiy regulates the "corporation-stakeholder relationship" in the domain } \\
\text { of sustainability accounting. }\end{array}$ \\
\hline Be to study & S & Agency theory is to study information asymmetry. \\
\hline Be underpinned by & U & "New school" (of sustainability accounting) is underpinned by stakeholder primacy. \\
\hline
\end{tabular}

\subsection{Colors and Their Implications}

Colors are used to highlight "accounting changes" from bifurcations, which result in germination of a new accounting branch or a new twig within the branch. We render further implications of colors used in this accounting tree, as shown in the Table 4.

Table 4. Colors and implications in the accounting concept tree.

\begin{tabular}{|c|c|c|}
\hline Objects & Color & Implications \\
\hline Bifurcations & Deep blue & $\begin{array}{l}\text { Deep blue represents wisdom. It implies potential to generate new sophisticated theoretical } \\
\text { perspectives or philosophies. }\end{array}$ \\
\hline Accountability & Brown & Brown is the color of soil, referring to accountability as the root for the whole accounting system. \\
\hline $\begin{array}{l}\text { Financial accounting } \\
\text { (trunk) }\end{array}$ & Gold & The gold color denotes the for-profit assumption of (traditional corporate) financial accounting. \\
\hline $\begin{array}{l}\text { Sustainability } \\
\text { accounting (branch) }\end{array}$ & $\begin{array}{l}\text { Green }+ \\
\text { Gold }\end{array}$ & $\begin{array}{l}\text { The new school is colored with green, aiming at improving environmental and } \\
\text { social performance. } \\
\text { The old school adopts the same color of gold as financial accounting. This is in accordance with } \\
\text { the view that old school holds a "for-profit" (shareholder primacy) element, and it is part of } \\
\text { financial accounting. }\end{array}$ \\
\hline $\begin{array}{l}\text { Public-sector } \\
\text { accounting (branch) }\end{array}$ & Sky blue & $\begin{array}{l}\text { Sky blue stands for harmony and trustworthiness, associated with the "for the public" } \\
\text { assumption of public-sector accounting. }\end{array}$ \\
\hline $\begin{array}{c}\text { Alternative } \\
\text { measurement (twig) }\end{array}$ & Yellow & $\begin{array}{l}\text { Yellow refers to opportunity and awareness, highlighting alternative measurement methods as } \\
\text { "alternatives" to the traditional historical costing in making managerial decisions. }\end{array}$ \\
\hline $\begin{array}{l}\text { Capital market } \\
\text { research (sub-twig) }\end{array}$ & Red & Red implies good signs or prosperousness in capital markets. \\
\hline $\begin{array}{l}\text { Creative accounting } \\
\quad \text { (sub-twig) }\end{array}$ & Grey & $\begin{array}{l}\text { Creative accounting is a "grey zone" in financial reporting, exploiting loopholes in financial } \\
\text { reporting regulation to gain advantages. It is not illegal but deviates from the } \\
\text { spirit of accounting. }\end{array}$ \\
\hline
\end{tabular}

\subsection{The Curriculum Concept Tree of Accounting Theory}

Figure 2 is the product of the tree-like concept map for the curriculum of Accounting Theory. In the figure, accounting theories and concepts are modeled into a tree. Located at the root is 
accountability, which represents the foundation of accounting practices. The accountability root buttressed the financial accounting trunk (main branch) and the branches of public-sector accounting and sustainability accounting. This layout visualizes the theory that accountability underlies all accounting phenomena, and different accountor-accountee relationships regulate various sector-specific accounting practices $[33,42,46-48]$. The bifurcation signposts indicate the difference between accounting sectors (branches), academic schools and streams (twigs), and sector-specific standards, principles, and practical models (sub-twigs and lower-level sub-twigs).

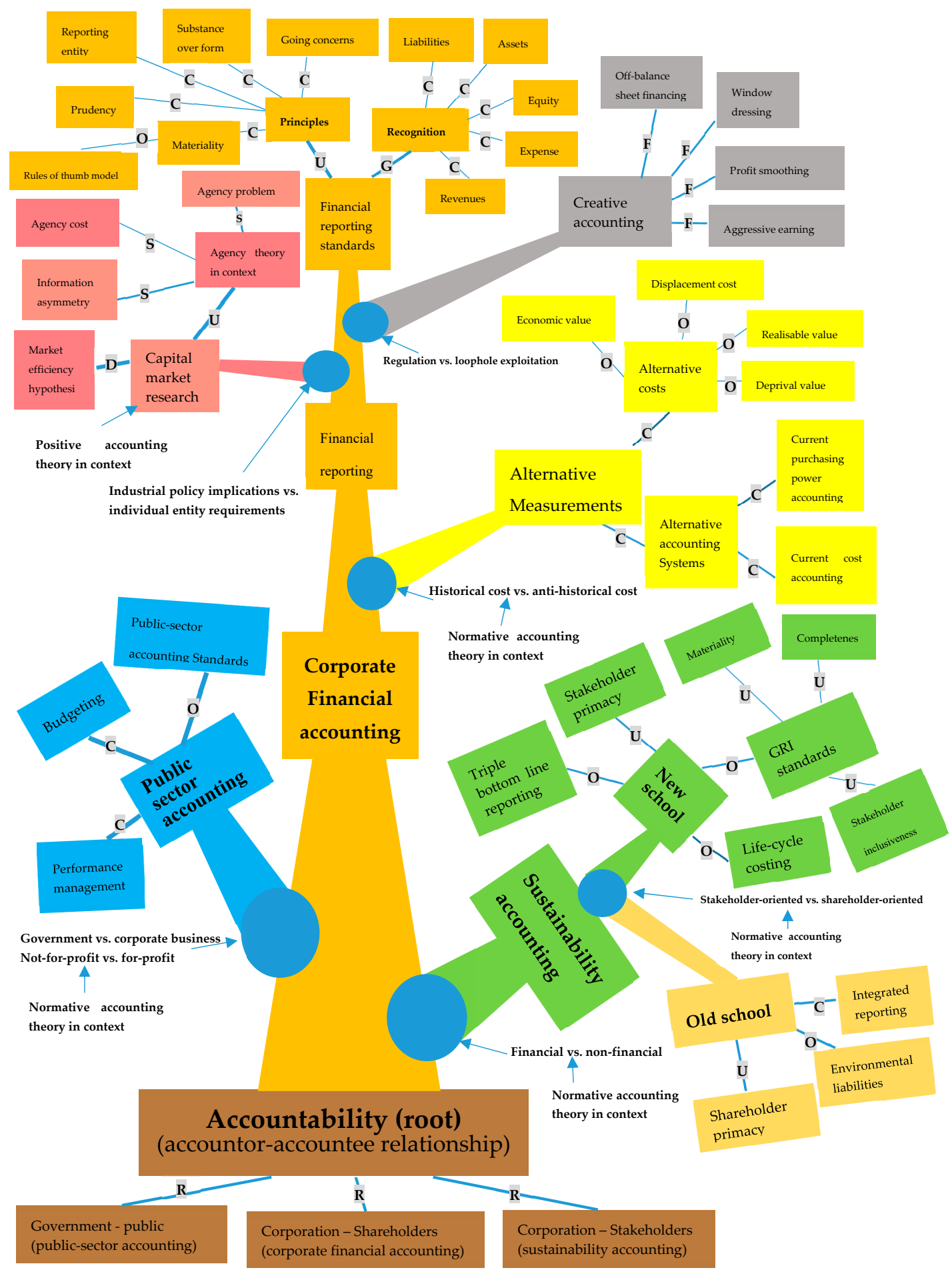

Figure 2. The concept tree of Accounting Theory. 


\subsection{A Comparison between the Two Curriculum Concept Maps}

Table 5 outlines some main characteristics of this concept tree in contrast to Simon (2007)'s curriculum concept map of financial accounting theory.

Table 5. The main differences between Simon's map and the concept tree.

\begin{tabular}{|c|c|c|c|}
\hline $\begin{array}{l}\text { Comparative } \\
\text { Themes }\end{array}$ & $\begin{array}{l}\text { The Old Concept Map } \\
\text { (Simon 2007) [4] }\end{array}$ & $\begin{array}{c}\text { The Concept Tree } \\
\text { (Developed in this Paper) }\end{array}$ & Comments on the Redesign \\
\hline Accountability & Not included. & $\begin{array}{l}\text { Highlighted as the } \\
\text { foundation of accounting } \\
\text { practices. }\end{array}$ & $\begin{array}{l}\text { Addressing the exceptionally important } \\
\text { accountability perspective to } \\
\text { accounting. }\end{array}$ \\
\hline $\begin{array}{l}\text { Public sector } \\
\text { accounting }\end{array}$ & Not covered. & $\begin{array}{l}\text { Public-sector accounting is } \\
\text { diverged from traditional } \\
\text { (corporate) financial } \\
\text { accounting. }\end{array}$ & $\begin{array}{l}\text { Addressing public-sector accounting } \\
\text { that is not for profit and not applied in } \\
\text { the business environment. }\end{array}$ \\
\hline $\begin{array}{l}\text { Environmental and } \\
\text { social perspectives of } \\
\text { accounting }\end{array}$ & $\begin{array}{l}\text { Taken as part of financial } \\
\text { accounting. }\end{array}$ & $\begin{array}{c}\text { Sustainability } \\
\text { (environmental and social) } \\
\text { accounting is diversified } \\
\text { from financial accounting } \\
\text { and encompasses two } \\
\text { streams. }\end{array}$ & $\begin{array}{l}\text { The old school having a } \\
\text { shareholder-primacy orientation is } \\
\text { closely related to financial accounting, } \\
\text { intimating the traditional view } \\
\text { presented in Simon's map. } \\
\text { The new school holding non-financial } \\
\text { and stakeholder-based elements has } \\
\text { become mainstream in sustainability } \\
\text { accounting. The new school is beyond } \\
\text { the scope of Simon's map. }\end{array}$ \\
\hline $\begin{array}{l}\text { Comparison and } \\
\text { contrast }\end{array}$ & $\begin{array}{l}\text { It fails to recognize the } \\
\text { alternative perspectives and } \\
\text { lacks comparisons and } \\
\text { contrasts between them. }\end{array}$ & $\begin{array}{c}\text { Comparisons between } \\
\text { concepts are used to indicate } \\
\text { how accounting } \\
\text { contexts/sectors and streams } \\
\text { are diversified. }\end{array}$ & $\begin{array}{l}\text { Addressing accounting evolution; } \\
\text { justifying how new accounting systems } \\
\text { and streams/schools were developed } \\
\text { from the traditional venue. }\end{array}$ \\
\hline Linking phrases & $\begin{array}{l}\text { Focuses on only two simple } \\
\text { terms, "can be" and "e.g.", } \\
\text { to describe the relationships. }\end{array}$ & $\begin{array}{l}\text { Uses multiple technical } \\
\text { terms to indicate the } \\
\text { relationships. }\end{array}$ & $\begin{array}{l}\text { Elucidating the complex relationships } \\
\text { between accounting concepts. }\end{array}$ \\
\hline $\begin{array}{l}\text { Accounting research } \\
\text { methodology }\end{array}$ & $\begin{array}{l}\text { Presented as } \\
\text { individual streams. }\end{array}$ & $\begin{array}{l}\text { Consolidated in accounting } \\
\text { contexts/sectors. }\end{array}$ & $\begin{array}{l}\text { Providing a concrete understanding on } \\
\text { accounting research methodology. }\end{array}$ \\
\hline
\end{tabular}

\section{Educational Insights}

Embedded with a research-centered element, the Accounting Theory curriculum is destined to assist students in comprehending the consolidation of accounting thoughts and discoveries, opening a door for them to probe into the nature of accounting phenomena. The concept tree plays an informative role to substantiate this essential aspect of the curriculum.

\subsection{Feeling the Pulses of Accountancy Development}

As an alternative to the old curriculum map [4], this concept tree embraces the advanced perspectives that have profoundly reframed the system of accounting knowledge. It enables students to update their theoretical understanding on accounting and then feel the pulses of accountancy development. In teaching practices, students are advised to compare the old and the new concept map and to clarify the major changes in accounting theories, including the general acceptance of the accountability-root view and the classification of accounting contexts/sectors that are regulated by different accountor-accountee relationships.

The elucidation is then prolonged according to this tree layout through introducing and commenting on the most recent theoretical debates associated with non-financial accountings, such as "business-like public sector accounting", "intelligent accountability", "theological or religious aspect of accountability", and "non-human stakeholders in sustainability accounting". These debates involve sharp critiques and radical ideas that have not been generally accepted or have remained exceptionally unpopular. However, they do represent cutting-edge understandings and brave attempts to promote advancement of accounting theories. Informed by the tree map, students not only acknowledge the new imperative 
accounting philosophies that have reformed the knowledge system, but also develop a precious spirit of critical thinking voiced from the infrequent endeavors in challenging the status quo.

\subsection{Addressing Accounting Evolution}

An advantage of this concept tree is its capacity to display and justify how accounting evolved and is evolving, which is attributed to the use of bifurcation signposts between different branches and between different twigs in a branch. To illustrate this, in contrast to the mainstream financial accounting (trunk) in pursuit of financial profits for individual business entities, public-sector accounting (branch) rests on a not-for-profit and public interest element, and sustainability accounting (branch) is developed to address non-financial and non-profit concerns. The bifurcation signposts between the trunk and the two new accounting branches characterize the base and the vein of how the two non-financial accounting systems emerged from critiques of the traditional accounting suppositions.

In a teaching setting, this concept tree is integrated in a story-telling method, where students can learn the accounting theories from a historical perspective. It was found that this innovative approach not only raised students' interests in studying theories themselves, but also triggered their enthusiasm in exploring the socio-economic backgrounds on which these theories were engendered. For example, presentation of the history of deprival value is complemented by the concept tree in the lecture. The bifurcation signpost between the twigs of financial reporting and alternative measurement informs that the deprival value contends an opposing stance against the historical cost assumption on which financial reporting standards are based. Associated with this bifurcation is a sequence of critical thinking questions regarding the invention of deprival value: (1) What were the problems of historical cost assumption when applied in practice? (2) How did the deprival value enable one to solve these problems? (3) How did the deprival value influence a generation of accounting scholars? (4) What lessons and experiences can we learn from this story regarding accounting evolution? These questions, ascribed to the historic story of deprival value, led students to probe into a deeper understanding of this accounting concept, motivating them to deliberate the nature and the practical implications of accounting evolution.

\subsection{Understanding Accounting Research Methodology in Contexts}

The distinction between the two research methods-normative accounting and positive accounting - is basic knowledge in this curriculum. Compared to the traditional way of paralleling the accounting research methodology to the practical accounting systems (as shown in Simon's map (2007) [10], this concept tree integrates the methodological understanding across and within accounting contexts. For instance, the concept tree illustrates the origin of positive accounting in the field (twig) of capital market research $[49,50]$, and the normative accounting research is associated with the critique of existing theories and the exploration of alternative theories (refer to the bifurcation signposts). This is evidenced in the emergence of new branches or twigs in the concept tree. Sustainability accounting can be understood as one example of normative theory, for this new accounting system with a non-financial element is used to substitute for the traditional financial accounting routines in dealing with non-financial environmental and social issues [12]. The alternative measurements can be viewed as another example of normative theory, in which the historical cost assumption is refused due to its inability to reflect current value and future benefit.

\subsection{Enhancing Understanding of Sector-Specific Accounting Practices}

The context- or sector-specificity of accounting practices as a relatively new philosophic perspective has gained prominence in the accounting academy [42,51,52]. It argues that, provided an accounting principle is applicable to different accounting sectors/contexts (such as financial business accounting, governmental accounting, and sustainability accounting), practical models and operationalization methods of this principle vary significantly across these accounting sectors $[12,42,44,53]$. The concept tree reinforces the understandability of this important perspective, guiding students to observe, 
deliberate, and analyze the sector-dependent nature of accounting phenomena. For example, the GRI sustainability reporting standards and the financial reporting standards symbolize sub-twigs from different accounting branches in the concept tree. This graphic outlook enables an immediate grasp of the differences between the two reporting systems and provides a foundation for the later implementation of concrete cases, through which these differences are investigated in detail, from reporting principles to procedures and formats.

Another application exemplar is the research case of operationalizing the materiality principle in practices. The accounting academy has observed that public-sector accountants and auditors tend to apply a much stricter materiality level (significance of an issue) than their corporate financial peers $[53,54]$. That is, an issue that is considered insignificant from the view of corporate accountants and auditors may be regarded as significant for public-sector accounting practices. Theorists attribute this variance to the different scopes of accountability, where financial accounting practitioners are accountable to only a small group of shareholders, whilst public-sector accountants/auditors bear accountability to the whole society $[53,55]$. The concept tree enables a graphic reference to understand this phenomenon, where the materiality sub-twigs appear in the different branches of traditional financial accounting and public-sector accounting, and the two branches are regulated by different accountor-accountee relationships. This graphic reference drawn from the concept tree has been used to introduce the sector-specific materiality phenomenon and the relevant theoretical explanations, thereby enhancing a meaningful learning manner through which the theories are visualized [21,22].

\section{Notes to the Curriculum Design}

The concept tree performs a function of designing and steering the curriculum. The curriculum design experiences pertinent to its application are documented as follows.

\subsection{Sequence of Lecture Topics}

Concept mapping is a useful vehicle for educators to "consider sequencing of topics" (p. 305) [11], a critical requirement for curricula due to the linear nature of instructional processes [1]. The concept tree endorses a sequence of curriculum topics. To begin, the concept tree is introduced in the initial lecture (Topic 1) to outline the overall curriculum knowledge system. Topic 1 also involves a brief explanation of the accountability theory and the accounting research methodology as they pertain to normative and positive theories. The other topics of the curriculum are sequenced and correspond to different parts of the tree, such as: financial reporting system (Topic 2, mainstream/trunk), alternative measurements to historical costs (Topic 3, twig), capital market research (Topic 4, twig), accountability theory (Topic 5, root), sustainability accounting (Topic 6, branch), public-sector accounting (Topic 7, branch), and advanced issues in accounting theory (Topic 8). Except for the introductory Topic 1, the sequencing starts from the financial reporting system (Topic 2) and its closely related Topics 3 and 4 , and then to the non-financial accounting Topics 5, 6, and 7. The final topic, Topic 8, concerns progressive theses, antitheses, and debates in accounting studies, covering all previous topics.

The rationale inherent to this sequencing is in line with Ausubel's meaningful learning theory [21,22], which holds that an efficient learning process is produced when new knowledge can be related to knowledge already known. A prerequisite for the Accounting Theory (and Application) curriculum is the unit of Principles of Accounting, which conjoins with the topic of corporate financial reporting. As this topic contains knowledge that students are familiar with before they start the curriculum, it is set as the second topic immediately following the introductory topic. Accountability theory (Topic 5) is allocated before sustainability accounting (Topic 6). This arrangement is in accordance with an epistemic perspective that accountability theory is the ethical foundation for the development of sustainability accounting [13]. 


\subsection{Cohesion of Topics}

A problem pertains to the complex multifaceted content presented in the curriculum, where students often get lost in lectures due to difficulty relating individual knowledge pieces to the comprehensive picture [2]. To address this concern, the concept tree is displayed at the beginning of each lecture, highlighting the place of the current topic in the whole system of curriculum knowledge. During each lecture, students are inspired to use the bifurcation signposts to compare the current topic and the topics previously learned. For example, the bifurcation signpost, "industrial policy implications versus individual entity accounting requirements", indicates the difference of scope and purpose between the two topics/twigs-capital market research and financial reporting system. In the lecture of capital market research (Topic 3), this signpost provides hints for students to further develop their understanding by referring to Topic 2 :

(1) how positive accounting researchers, whose work is to discover behavioral modes of companies in response to different accounting (Topic 3), play different roles from corporate accountants, who prepare financial reports according to the pre-set standards (Topic 2); and

(2) how to apply the agency theory in the capital market context (Topic 3) to prevent creative accounting problems associated with financial reporting standards (Topic 2).

\subsection{A Meaningful Learning Mode of Exam Design}

To our teaching experiences, exam questions prepared for this curriculum are easily designed on "a mode of rote learning" [21], which requires students to restate the definitions of accounting theories and concepts. The memory-test exam questions fail to assess whether students have really comprehended the theoretical knowledge and whether they are able to apply theories to practices. The concept tree can be useful to design consolidated case-based exam questions that integrate different accounting models, therefore attaining "the mode of meaningful learning" [21]. This application is shown in the following sample exam questions (Box 1).

Box 1. Memory-test (rote learning) questions prepared for the exam.

Question 1: Define the normative accounting theory;

Question 2: Define the historical cost assumption;

Question 3: Discuss the advantages and the disadvantages of the historical cost method;

Question 4: Present the straight-line depreciation model to recognize a fixed asset;

Questions 5: Explain these values: market value, net realizable value, economic value.

These exam questions simply require students to remember the textbook-based definitions and calculation formulas. The memory-test method to which the sample questions adhere is typical of rote learning and has been seriously critiqued in educational literature [1,21,22,56].

It is an attempt to redesign these questions in favor of a meaningful learning style. The first step is to establish a reference for these questions in the tree-shaped concept map, as shown in Table 6.

The bifurcation signpost, "historical cost versus anti-historical cost", indicates the fundamental differences between the two different twigs to which the financial reporting and the alternative costs belong, respectively. Furthermore, this signpost links to the adjacently noted "in-context normative theory", which was developed on the critique of the traditional historical cost. These connections form the condition under which it is possible to design a case used to integrate the separated knowledge pieces into a consolidated body for the exam, which is shown in Box 2.

Compared to exam questions in Box 1, which require students to replicate the definitions of individual concepts or formulas of the models, the exam redesign (Box 2) inspired by the concept tree synthesizes different knowledge pieces into a concrete, sophisticated, and practice-based case, which enables a more effective test of students' conceptual understandings and practical applications. 
Table 6. Examined knowledge pieces in reference to the concept tree.

\begin{tabular}{|c|c|}
\hline Examined Knowledge Pieces & Reference to the Concept Tree \\
\hline Financial reporting of a fixed asset & $\begin{array}{l}\text { A lower-level sub-twig in the financial accounting } \\
\text { standards twig }\end{array}$ \\
\hline Calculation models of alternative values & Sub-twigs of alternative costs twig \\
\hline $\begin{array}{l}\text { Applications of the alternative values in } \\
\text { decision-making }\end{array}$ & The twig of alternative costs \\
\hline The historical cost assumption & $\begin{array}{l}\text { The bifurcation signpost between twigs of financial } \\
\text { accounting and alternative measurements }\end{array}$ \\
\hline The positive and the normative accounting theory & $\begin{array}{l}\text { In-context normative accounting theory associated to } \\
\text { the twig of alternative measurement }\end{array}$ \\
\hline
\end{tabular}

Box 2. A meaningful learning redesign of exam questions.

On 1 January 20X5, a company purchased a machine at a cost of \$2000. It has a useful life estimated to be 8 years, and this machine has a residual value of $\$ 400$.

At 31 December 20X7, it was estimated that the machine could be sold for $\$ 4000$. However, if the company could provide maintenance for this machine, it would be sold for $\$ 10,000$. The maintenance fee was $\$ 2000$. If the company continued to use the machine, management estimated that it would generate net cash inflows of $\$ 2000$ each year during the remaining useful life.

Required:

(1) Calculate the amount of value for this asset shown in the financial report at the year-end $20 X 7$.

(2) Calculate the market value, the net realizable value, and the economic value at the end of 20X7. At that time, the company had three options to deal with the machine: to sell the machine directly, to sell it after maintenance, and to keep it. What would be the best option from an economic view?

(3) Use this case to discuss the advantages and the disadvantages of the historical cost method to value a fixed asset. Suppose you try to write a research paper using this case in which you maintain a stance of advocating alternative costing and critiquing the traditional historical cost method. Is your research classified to positive or normative accounting theory?

\section{Conclusions}

This paper is intended to extend the interpretational and the applicable capacity of concept mapping in accounting education, prompted by a knowledge gap that no suitable concept map has filled to interpret the current state of the Accounting Theory curriculum knowledge system, which has undergone rapid and significant development. The key molded by this paper to resolve this problem is a tree-form concept map, which systematically models the progressive curriculum knowledge into a tree-like structure, including the root, the trunk, the branches, the twigs, the sub-twigs, and the bifurcations.

The contribution of this study is trifold. First, it enriches the concept mapping methodology through an exemplary case of the scarcely documented "tree-shaped" mapping method and its application in an accounting education setting. This paper thus informs educators and concept mappers of the values and the characteristics of concept trees, conveying the potential to apply and generalize this particular mapping technique to other curriculums or courses.

Second, the concept tree itself denotes a creative theoretical model that concludes the accounting knowledge system, which has been significantly restructured and advanced by newly emerging theories. Compared to the previous limited mapping work [10], the concept tree assimilates the advanced and the prominent knowledge claims that accountability is theorized as both the base of accounting practices and as the rationale, according to which financial and non-financial accounting contexts/sectors are distinctly classified [12,44]. Furthermore, with a faculty of interpreting the complex interrelationships between concepts, this tree-shaped redisposition provides a reference to a deeper form of wisdom concerning the accounting evolution, the accounting research methodology, and the sector-specific accounting phenomena. 
The curriculum development that the concept tree facilitates is the third contribution. The tree-shaped concept map sets visual guidelines for educators to sequence and cohere topics, thereby enabling students to concisely communicate the voluminous and complex information that encompasses many aspects of the curriculum [57]. In addition, this concept tree has proved to be a useful device in designing exam questions, by which the pedagogy is redirected from a memory-test mode toward a meaningful learning track, where students are required to make efforts to comprehend, integrate, and apply their theoretical knowledge into concrete practices.

Funding: This research received no external funding.

Conflicts of Interest: The author declares no conflict of interest.

\section{References}

1. Novak, J.D.; Gowin, D.B. Learning How to Learn; Cambridge University Press: New York, NY, USA, 1984.

2. Canas, A.J. A Summary of Literature Pertaining to the Use of Concept Mapping Techniques and Technologies for Education and Performance Support; The Institute for Human and Machine Cognition: Pensacola, FL, USA, 2003.

3. Schwendimann, B. Concept mapping. In Encyclopedia of Science Education; Gunstone, R., Ed.; Springer: Amsterdam, The Netherlands, 2015.

4. Wise, A.M. Map It: How Concept Mapping Affects Understanding of Evolutionary Processes. Ph.D. Thesis, University of California, Davis, CA, USA, 2009.

5. Schwendimann, B.A. Concept maps as versatile tools to integrate complex ideas: From kindergarten to higher and professional education. Knowl. Manag. E-Learn. 2015, 7, 73-99.

6. Bridges, S.M.; Corbet, E.F.; Chan, L.K. Designing problem-based curricula: The role of concept mapping in scaffolding learning for the health sciences. Knowl. Manag. E-Learn. 2015, 7, 119-133.

7. Hay, D.B.; Proctor, M. Concept maps which visualise the artifice of teaching sequence: Cognition, linguistic and problem-based views on a common teaching problem. Knowl. Manag. E-Learn. 2015, 7, 36-55.

8. Cañas, A.J.; Novak, J.D.; Reiska, P. How good is my concept map? Am I a good Cmapper? Knowl. Manag. E-Learn. 2015, 7, 6-19.

9. Kinchin, I.M. Concept Mapping as a Learning Tool in Higher Education: A Critical Analysis of Recent Reviews. J. Contin. High. Educ. 2014, 62, 39-49. [CrossRef]

10. Simon, J. Concept mapping in a financial accounting theory course. Acc. Educ. 2007, 16, 273-308. [CrossRef]

11. Leauby, B.A.; Szabat, K.; Mass, J.D. Concept mapping-An empirical study in introductory financial accounting. Acc. Educ. 2010, 19, 279-300. [CrossRef]

12. Lamberton, G. Sustainability accounting-A brief history and a conceptual framework. Acc. Forum 2005, 29, 7-26. [CrossRef]

13. Roberts, J. No one is perfect: The limits of transparency and an ethic for 'intelligent' accountability. Acc. Organ. Soc. 2009, 34, 957-970. [CrossRef]

14. Schaltegger, S.; Burritt, R.L. Sustainability accounting for companies: catchphrase or decision support for business leaders? J. World Bus. 2010, 45, 375-384. [CrossRef]

15. Shearer, T. Ethics and accountability: from the for-itself to the for-the-other. Acc. Organ. Soc. 2002, 27, 541-573. [CrossRef]

16. Simon, J. Curriculum changes using concept maps. Acc. Educ. 2010, 19, 301-307. [CrossRef]

17. Vanides, J.; Yin, Y.; Tomita, M.; Ruiz-Primo, M.A. Using concept maps in the science classroom. Sci. Soc. 2005, 28, 27-31.

18. Solvie, P.A.; Sungur, E. Concept maps/graphs/trees/vines in education. Presented at the 5th WSEAS International Conference on E-ACTIVITIES, Venice, Italy, 20 November 2006.

19. Gilmour, S.J. Daz Sint Noch Ungelogenius Wort: A Literary Linguistic Commentary on Gurnemanz, Episode. In Book III of Wolfram's Parzival; Universitatsverlag Winter: Heidelberg, Germany, 2000.

20. Alexandre, F. Trees, waves and linkages: models of language diversification. In The Routledge Handbook of Historical Linguistics; Bowern, B., Evans, C., Eds.; Routledge: New York, NY, USA, 2014; pp. 161-189.

21. Ausubel, D. The Psychology of Meaningful Verbal Learning; Grune \& Stratton: Oxford, UK, 1963. 
22. Ausubel, D. The Acquisition and Retention of Knowledge: A Cognitive View; Springer: Amsterdam, The Netherlands, 2012.

23. Ausubel, D. The use of advance organizers in the learning and retention of meaningful verbal material. J. Educ. Psychol. 1960, 5, 267-272. [CrossRef]

24. Mayer, R.E. Can advance organizers influence meaningful learning? Rev. Educ. Res. 1979, 49, 371-383. [CrossRef]

25. Ausubel, D. Educational Psychology: A Cognitive View; Holt, Rinehart and Winston: New York, NY, USA, 1968.

26. Rovira, C. Theoretical foundation and literature review of the study of concept maps using eye tracking methodology. Prof. Inf. 2016, 25, 59-73. [CrossRef]

27. Handy, S.A.; Polimeni, R.S. Concept mapping-A graphical tool to enhance learning in an introductory cost or managerial accounting course. J. Acad. Bus. Educ. 2017, 18, 161-174.

28. Mass, J.D.; Leauby, B.A. Active learning and assessment: A student guide to using concept mapping in financial accounting. Glob. Perspect. Acc. Educ. 2014, 11, 41-63.

29. Shimerda, T.A. Concept mapping: A technique to aid meaningful learning in business and accounting education. Indian J. Econ. Bus. 2007, 6, 117-124.

30. Mass, J.D.; Leauby, B.A. Concept mapping-Exploring its value as a meaningful learning tool in accounting education. Glob. Perspect. Acc. Educ. 2005, 2, 75-98.

31. Cañas, A.J.; Novak, J.D. Concept mapping using cmap tools to enhance meaningful learning. In Knowledge Cartography: Software Tools and Mapping Techniques; Okada, A., Shum, S.B., Sherborne, T., Eds.; Springer-Verlag: London, UK, 2008; pp. 25-46.

32. Kinchin, I.M. Pedagogic frailty: A concept analysis. Knowl. Manag. E-Learn. 2017, 9, 295-310.

33. Gray, R.; Adams, C.; Owen, D. Accountability, Social Responsibility and Sustainability: Accounting for Society and the Environment; Pearson Education Limited: London, UK, 2014.

34. Goetz, A.; Jenkins, R. Voice, Accountability and Human Development: The Emergence of a New Agenda; United Nations Development Programme: New York, NY, USA, 2002.

35. Mashaw, J. Accountability and institutional design: Some thoughts on the grammar of governance. In Public Accountability: Designs, Dilemmas and Experiences; Dowdle, M.W., Ed.; Cambridge University Press: Cambridge, UK, 2006; pp. 115-156.

36. Schedler, A. Conceptualizing accountability. In The Self-Restraining State: Power and Accountability in New Democracies; Schedler, A., Diamond, L., Plattner, M., Eds.; Lynne Rienner Publishers: London, UK, 1999; pp. 13-28.

37. Bovens, M. Analysing and assessing accountability: A conceptual framework. Eur. Law J. 2007, 13, 447-468. [CrossRef]

38. Australia Auditing Standard Board. Materiality and Audit Adjustments AUS 306; Australian Accounting Research Foundation: Melbourne, Australia, 2001.

39. Global Reporting Initiative. G4 Sustainability Reporting Guidelines (GRI G4); GRI: Amsterdam, The Netherlands, 2013.

40. AccountAbility. AA1000 AccountAbility Principles Standard 2008 (AA1000APS 2008); AccountAbility: London, UK, 2008.

41. Murninghan, M. Redefining Materiality II: Why it Matters, Who's Involved, and What it Means for Corporate Leaders and Boards; AccountAbility: London, UK, 2013.

42. Zhou, Y. Materiality in Sustainability Accounting: A Critical Realist Perspective. Ph.D. Thesis, Southern Cross University, Lismore, Australia, 2017.

43. Anon. IFAC Public Sector Meets in New Zealand. Acc. J. 1993, 72, 34-37.

44. Barton, A. Professional accounting standards and the public sector-A mismatch. Abacus 2005, 41, 138-158. [CrossRef]

45. Meyer, J.; Land, R. Threshold Concepts and Troublesome Knowledge: Linkages to Ways of Thinking and Practising within the Disciplines; University of Edinburgh: Edinburgh, UK, 2003; pp. 412-424.

46. Christensen, M.; Newberry, S.; Potter, B. Enabling global accounting change: Epistemic communities and the creation of a 'more business-like' public sector. Crit. Perspect. Acc. 2019, 58, 53-76. [CrossRef]

47. Herath, G. Sustainable development and environmental accounting: the challenge to the economics and accounting profession. Int. J. Soc. Econ. 2005, 32, 1035-1050. [CrossRef]

48. Hardy, L.; Ballis, H. Accountability and giving accounts. Acc. Audit. Acc. J. 2013, 26, 539-566. [CrossRef] 
49. Ball, R.; Brown, P. An empirical evaluation of accounting income numbers. J. Acc. Res. 1968, 6, $159-178$. [CrossRef]

50. Watts, R.L.; Zimmerman, J.L. Towards a positive theory of the determination of accounting standards. Acc. Rev. 1978, 53, 112-134.

51. Modell, S. In defence of triangulation: A critical realist approach to mixed methods research in management accounting. Manag. Acc. Res. 2009, 20, 208-221. [CrossRef]

52. Modell, S. Critical realist accounting: In search of its emancipatory potential. Crit. Pers. Acc. 2017, 42, $20-35$. [CrossRef]

53. Zhou, Y.; Zhou, G. Establishing judgement about materiality in government audits: Experience from Chinese local government auditors. Int. J. Gov. Audit. 2011, 38, 9-14.

54. Raman, K.; Van Daniker, R. Materiality in government auditing. J. Acc. 1994, 177, 71-76.

55. DeZoort, T.; Harrison, P.; Taylor, M. Accountability and auditors' materiality judgments: the effects of differential pressure strength on conservatism, variability, and effect. Acc. Organ. Soc. 2006, 31, 373-390. [CrossRef]

56. Novak, J.D. Learning, Creating, and Using Knowledge: Concept Maps as Facilitative Tools in Schools and Corporations; Lawrence Erlbaum Association: Mahwah, NJ, USA, 1998.

57. Edmondson, K.M. Concept maps as reflectors of conceptual understanding. J. Res. Sci. Teach. 1983, 13, $19-26$.

(C) 2019 by the author. Licensee MDPI, Basel, Switzerland. This article is an open access article distributed under the terms and conditions of the Creative Commons Attribution (CC BY) license (http://creativecommons.org/licenses/by/4.0/). 